University of Nebraska - Lincoln

DigitalCommons@University of Nebraska - Lincoln

Publications from USDA-ARS / UNL Faculty

U.S. Department of Agriculture: Agricultural

Research Service, Lincoln, Nebraska

2001

Grain color stability and classification of hard white wheat in the

U.S.

C. J. Peterson

D. R. Shelton

T. J. Martin

R. G. Sears

E. Williams

See next page for additional authors

Follow this and additional works at: https://digitalcommons.unl.edu/usdaarsfacpub

Part of the Agricultural Science Commons

Peterson, C. J.; Shelton, D. R.; Martin, T. J.; Sears, R. G.; Williams, E.; and Graybosch, R. A., "Grain color stability and classification of hard white wheat in the U.S." (2001). Publications from USDA-ARS / UNL Faculty. 225.

https://digitalcommons.unl.edu/usdaarsfacpub/225

This Article is brought to you for free and open access by the U.S. Department of Agriculture: Agricultural Research Service, Lincoln, Nebraska at DigitalCommons@University of Nebraska - Lincoln. It has been accepted for inclusion in Publications from USDA-ARS / UNL Faculty by an authorized administrator of DigitalCommons@University of Nebraska - Lincoln. 


\section{Authors}

C. J. Peterson, D. R. Shelton, T. J. Martin, R. G. Sears, E. Williams, and R. A. Graybosch

This article is available at DigitalCommons@University of Nebraska - Lincoln: https://digitalcommons.unl.edu/ usdaarsfacpub/225 


\title{
Grain color stability and classification of hard white wheat in the U.S.
}

\author{
C.J. Peterson, D.R. Shelton, T.J. Martin, R.G. Sears, E. Williams \& R.A. Graybosch \\ ${ }^{1}$ Oregon State University, Corvallis, OR, USA; Wheat Marketing Center, Portland, OR, USA; Kansas State Uni- \\ versity, Manhattan, KS, USA; ${ }^{2}$ Agripro Seeds, Inc., Berthoud, CO, USA; USDA-GIPSA, Kansas City, MO, USA; \\ ${ }^{3} U S D A-A R S$, Lincoln, NE, USA
}

Key words: classification, end-use quality, hard white wheat, stability

\begin{abstract}
Variability in grain color of hard white wheat was investigated in cultivars grown over two years in Nebraska and Kansas and related to variation observed in grain hardness, kernel weight, kernel size, and protein content and to color of ground meal and flour. Grain color was scored subjectively, through visual evaluation, and objectively through use of a colorimeter. Of the 543 hard white wheat samples examined by USDA-GIPSA grain inspectors, 15.5\% were scored as visually darker than the 1990 grain color standard established as a minimum for hard white wheat classification. The remaining samples were scored as having grain color essentially equal $(28.2 \%)$, or visually 'whiter' (56.4\%), than the color standard. Distributions of colorimeter $\mathrm{L}$, a, and b values suggest that the colorimeter had difficulty in capturing the subtleties of visual ratings. There were significant decreases in kernel hardness and grain protein content among samples that scored visually 'whiter' than the color standard. Grain color, measured either visually or by colorimeter, was not a reliable indicator of either ground meal color or flour color. As such, it may provide little indication of grain quality, end-product color, or processing value to the milling and baking industries.
\end{abstract}

\section{Introduction}

Grain color of hard white wheat cultivars must be sufficiently 'white' to readily discriminate grain from hard red wheats, to consistently meet grain classification standards, and meet domestic and export market demands of end-users. A minimum grain color standard was first established by the Federal Grain Inspection Service of USDA-GIPSA in 1990, when hard white wheat was officially recognized as a unique market class in the U.S. The color standard was based on a grain sample from the hard white wheat variety 'Klasic' produced in California. It provided a simple, subjective threshhold for color on which to visually identify and differentiate hard red and white wheat and provided a basis for identifying mixtures of red and white grain. However, the color standard was waived in 1994 when numerous samples of 'Klasic' were found with grain darker than the officially accepted standard. From 1994 to 1999 an interim classification procedure was used based on variety identity and pro- duction origin. The interim procedure was adequate, as there had been limited acreage of hard white wheat, grown mostly under identity-preserved marketing arrangements. However, with increasing interests in hard white wheat breeding and production, the interim classification procedure was no longer considered viable for the industry. Industry-wide discussions were subsequently held to re-implement a color standard. Although adoption was considered necessary for marketing hard white grain, visual-color remains a highly subjective and controversial means of classification. Rapid, objective test criteria are needed to more accurately differentiate among hard red and hard white grains, facilitate classification by the industry, and identify class mixtures throughout market channels.

For many years, U.S. breeders have expressed concern over the use of a minimum color standard for hard white wheat classification. Significant variation for grain color exists among genotypes of hard white wheat. In addition to three major loci controlling red seed color, there may be as many as 
six minor genes influencing grain color (Freed et al., 1976; Reitan, 1980). Of more concern, however, is the impact that environment and management practices may have on grain color. Visual differentiation of weathered samples of hard red and hard white grain can be very difficult. But, even if one considers only sound, unweathered grain samples, significant color variation exists in grain from a single variety grown over diverse production conditions (Wu et al., 1999). Environmentally induced variations in grain protein content, hardness, vitreousness (translucence), and kernel size and shape all may contribute to variation in visual grain color. The diversity in growing conditions and environmental stresses in the Great Plains, in particular, may make it difficult to achieve consistent hard white grain color, even with varieties that are genetically superior for grain color.

This study was conducted to examine variability in grain color characteristics of hard white wheat cultivars grown in Nebraska and Kansas. Specific objectives included: 1) document variation in hard white grain color over an array of production environments and cultivars; 2) evaluate use of a colorimeter as means to discriminate visual-color ratings of grain in relation to the 1990 USDA-GIPSA color standard; 3) characterize variations in grain hardness, kernel weight, kernel size, and protein content in relation to grain color; 4) examine color of ground meal, and flour to determine potential impact of hard white wheat grain color on end-use product applications.

\section{Materials and methods}

Eighteen hard white winter wheat cultivars and experimental lines were grown in yield trials throughout Kansas and Nebraska in 1996 and fourteen cultivars were grown in 1997. Each trial was grown using three replications and agronomic practices common to the respective production areas. Grain samples were obtained from trials at Colby, Hays, and Ness County, Kansas and Sidney and McCook Nebraska in 1996; and from trials at Colby, Garden City, Hays, and Tribune, Kansas, and Lincoln, McCook, and Sidney, Nebraska in 1997. A small number of plots were lost due to winterkilling. Some samples were discarded due to a high proportion of red wheat mixtures, due to either contamination prior to planting or during harvest. A total of 543 samples were used for analyses.

One-hundred g grain samples from each plot were provided to USDA-GIPSA, Kansas City, KS, for visual evaluation of grain color, and uniformity, in terms of visually contrasting classes. Grain samples were compared individually to the hard white wheat grain color standard established in 1990 from California production of the hard white variety 'Klasic'. A subjective scoring system of -2 to +2 was used, where a visual-color score of -2 was considered as a 'much darker' than the color standard sample; -1 as 'darker; +2 as 'much lighter'; +1 as 'lighter'; and 0 as 'essentially equal' to the color standard. These subjective scores were treated as discrete, rather than continuous, variables in subsequent statistical analyses.

Grain samples were then evaluated for color using a Minolta CR300 Colorimeter ${ }^{1}$ (Minolta Corp., Ramsey, NJ). A white CR-A43 ceramic tile was used for instrument calibration. Colorimeter $\mathrm{L}^{*}$ values represent 'lightness', with score of 100 as white and 0 as black (Morris et al, 2000). Colorimeter a* values reflect red-green colors with '+' values indicating 'redness', and '-' values as 'greenness'. Colorimeter $b^{*}$ values measure yellow to blue colors, with ' + ' values indicating 'yellowness' and '-' values indicating 'blueness'. Colorimeter scores were taken six times on each sample, which represents two sample loadings and three color measures per loading.

Grain samples were evaluated for grain hardness, kernel weight and size using the Perten SKCS 4100 single kernel characterization system (Perten Instruments North America, Reno, NV, USA). A subsample of grain was ground on a Udy cyclone mill (Udy Corp., Ft. Collins, CO, USA) to obtain a wholeground meal. The Minolta CR300 colorimeter was used to score color on the ground meal samples. Colorimeter scores were taken six times per sample, with two sample loadings and three color measures per loadings. Remaining grain samples were micro-milled on a Quadromat Jr. (C.W. Brabender Instruments, South Hackensack, NJ, USA) to provide flour. Flour color was evaluated, again using the Minolta colorimeter, using the same protocol as for meal samples. Grain protein was determined on ground whole grain samples using a Foss 6500 scanning NIR (Foss NIR systems, Silver Spring, MD, USA). The NIR protein calibrations were developed using a sample subset for combustion N analyses (Leco Corp., St. Joseph, MO, USA). Protein was adjusted to a common moisture level and expressed as $\mathrm{g} \mathrm{kg}^{-1}$ on a dry weight basis.

\footnotetext{
1 Mention of trademark or proprietary products does not constitute an endorsement, warranty, or approval to the exclusion of other available products.
} 
Table 1. Means and standard deviations of grain protein content, kernel hardness and weight, and colorimeter measures of grain, meal and flour color for hard white wheat samples of varying visual-color scores

\begin{tabular}{|c|c|c|c|c|c|c|c|c|c|c|c|c|c|}
\hline \multirow{2}{*}{$\begin{array}{l}\text { Visual } \\
\text { color } \\
\text { Score }^{1}\end{array}$} & \multirow[t]{2}{*}{$\mathrm{N}$} & \multicolumn{2}{|c|}{$\begin{array}{l}\text { Grain protein } \\
\mathrm{g} / \mathrm{kg}, \mathrm{dw}\end{array}$} & \multicolumn{2}{|c|}{$\begin{array}{l}\text { Kernel } \\
\text { hardness }\end{array}$} & \multicolumn{2}{|c|}{$\begin{array}{l}\text { Kernel } \\
\text { weight g }\end{array}$} & \multicolumn{2}{|l|}{$\begin{array}{l}\text { Grain } \\
\text { L }\end{array}$} & \multicolumn{2}{|l|}{$\begin{array}{l}\text { Grain } \\
\text { a }\end{array}$} & \multicolumn{2}{|l|}{$\begin{array}{l}\text { Grain } \\
b\end{array}$} \\
\hline & & Mean & $\mathrm{Sd}$ & Mean & $\mathrm{Sd}$ & Mean & $\mathrm{Sd}$ & Mean & $\mathrm{Sd}$ & Mean & Sd & Mean & $\mathrm{Sd}$ \\
\hline-2 & 12 & 156.2 & 21.8 & 62.8 & 9.0 & 32.5 & 4.3 & 41.81 & 1.71 & 4.49 & 0.44 & 16.09 & 1.63 \\
\hline-1 & 72 & 166.3 & 15.2 & 67.5 & 9.5 & 31.3 & 3.6 & 41.46 & 2.05 & 4.13 & 0.29 & 15.54 & 1.31 \\
\hline 0 & 153 & 166.1 & 18.0 & 68.5 & 8.3 & 30.6 & 3.2 & 41.04 & 1.71 & 4.24 & 0.31 & 14.95 & 1.37 \\
\hline 1 & 246 & 154.6 & 21.3 & 60.7 & 8.5 & 31.4 & 3.3 & 42.83 & 2.27 & 3.97 & 0.35 & 15.89 & 1.01 \\
\hline 2 & 60 & 157.3 & 12.5 & 55.6 & 9.6 & 33.6 & 3.1 & 44.56 & 1.61 & 3.88 & 0.27 & 17.30 & 1.00 \\
\hline $\begin{array}{l}\text { Visual } \\
\text { color }\end{array}$ & $\mathrm{N}$ & $\begin{array}{l}\text { Meal } \\
\text { L }\end{array}$ & & $\begin{array}{l}\text { Meal } \\
\mathrm{a}\end{array}$ & & $\begin{array}{l}\text { Meal } \\
\mathrm{b}\end{array}$ & & $\begin{array}{l}\text { Flour } \\
\text { L }\end{array}$ & & $\begin{array}{l}\text { Flour } \\
\mathrm{a}\end{array}$ & & $\begin{array}{l}\text { Flour } \\
\mathrm{b}\end{array}$ & \\
\hline Score & & Mean & $\mathrm{Sd}$ & Mean & $\overline{\mathrm{Sd}}$ & Mean & $\mathrm{Sd}$ & Mean & $\mathrm{Sd}$ & Mean & $\mathrm{Sd}$ & Mean & $\mathrm{Sd}$ \\
\hline-2 & 12 & 67.42 & 1.12 & 0.25 & 0.30 & 9.64 & 0.41 & 71.65 & 0.86 & -1.48 & 0.32 & 8.45 & 1.10 \\
\hline-1 & 72 & 67.55 & 0.80 & 0.20 & 0.24 & 9.56 & 0.41 & 71.81 & 0.87 & -1.33 & 0.29 & 8.04 & 0.91 \\
\hline 0 & 153 & 67.61 & 0.73 & 0.15 & 0.16 & 9.57 & 0.42 & 71.82 & 0.91 & -1.27 & 0.29 & 7.88 & 0.80 \\
\hline 1 & 246 & 67.81 & 0.80 & 0.09 & 0.17 & 9.43 & 0.39 & 72.00 & 0.75 & -1.37 & 0.27 & 7.59 & 0.75 \\
\hline 2 & 60 & 68.12 & 0.69 & 0.07 & 0.13 & 9.35 & 0.37 & 71.73 & 0.86 & -1.32 & 0.24 & 7.74 & 0.80 \\
\hline
\end{tabular}

Visual-color scores were determined in relation to the 1990 USDA-GIPSA color standard, with 0 as 'essentially equal' to the standard and + , and - scores as 'lighter' and 'darker' than the color standard, respectively.

Statistical analyses were conducted using Statistical Analysis System (SAS) programs (SAS Institute, Cary, NC). As there were unequal subclass numbers represented in the visual-color scores, differences in colorimeter measures and kernel characteristics were determined via Bonferroni paired t-tests with using visual-color score as a class variable in PROC GLM. Relationships among whole grain, ground meal, and flour color and physical kernel characteristics were determined by calculation of Pearson correlation coefficients.

\section{Results and discussion}

Of the 543 hard white wheat grain samples examined by USDA-GIPSA grain inspectors, $15.5 \%$ were scored as visually 'darker' (i.e., -1 or -2 ) than the 1990 color standard. The remaining samples were scored as having grain color essentially equal $(28.2 \%)$, or visually lighter (56.4\%), than the 1990 color standard. Grain samples scored as darker than the color standard were identified from 11 of the 12 growing locations. The percentage of the darker-colored samples from each location ranged from 0 up to $42 \%$, with eight locations having at least $10 \%$ of samples considered as darker than the color standard. In 1996, only one of 18 hard white cultivars produced grain that was equal or lighter than the color standard over all five growing locations and replications within locations. In 1997, only one of 14 cultivars had acceptable grain color over all field locations and replications.

The Minolta colorimeter provided precise and highly repeatable values for measuring grain color. Grain $L^{*}$ values ('lightness') for these hard white samples ranged from 36.65 to 49.09 units with average standard error of 0.23 for sample means. Grain a* values ('redness') ranged from 2.61 to 5.30 units with average standard error of 0.06 and b* values ('yellowness') ranged from 11.79 to 19.55 units with average standard error of 0.18 for sample means.

Means and standard deviations of colorimeter parameters were calculated for samples within each visual-color group (Table 1). Significant differences between visual-color groups were determined using Bonferroni paired t-tests (Table 2). Samples with visual-scores of +1 or +2 had significantly higher mean $\mathrm{L}^{*}$ and $\mathrm{b}^{*}$ value and lower $\mathrm{a}^{*}$ value than those scored as equal to the color standard. Samples with +2 scores also had significantly higher average $L^{*}$ and lower $b^{*}$ values than those of +1 ratings, but colorimeter $\mathrm{a}^{*}$ values were not different. However, colorimeter $\mathrm{L}^{*}$ and $\mathrm{a}^{*}$ values did not differ among sample groups with visual-scores of $-2,-1$, or 0 . Mean colorimeter $b^{*}$ values were higher for samples scored 
Table 2. Results of Bonferroni paired t-tests to identify significant differences in mean grain protein content, kernel hardness and weight, and colorimeter measure of grain, meal and flour color among groups of hard white wheat samples with varying visual-color scores

\begin{tabular}{|c|c|c|c|c|c|c|c|c|c|c|c|c|}
\hline \multirow[t]{2}{*}{$\mathrm{VCS}^{+}$} & \multirow[t]{2}{*}{ GP } & \multirow[t]{2}{*}{ KG } & \multirow[t]{2}{*}{ KW } & \multicolumn{3}{|c|}{ Grain } & \multicolumn{3}{|c|}{ Meal } & \multicolumn{3}{|c|}{ Flour } \\
\hline & & & & $\mathrm{L}^{*}$ & $\mathrm{a}^{*}$ & $\mathrm{~b}^{*}$ & $\mathrm{~L}^{*}$ & $a^{*}$ & $\mathrm{~b}^{*}$ & $\mathrm{~L}^{*}$ & $\mathrm{a}^{*}$ & $\mathrm{~b}^{*}$ \\
\hline$-2,-1$ & & & & & $*$ & & & & & & & \\
\hline$-2,0$ & & & & & & * & & & & & & \\
\hline$-2,1$ & & & & & $*$ & & & $*$ & & & & $*$ \\
\hline$-2,2$ & & & & * & $*$ & * & $*$ & * & & & & \\
\hline$-1,0$ & & & & & & $*$ & & & & & & \\
\hline$-1,1$ & * & * & & $*$ & $*$ & & & $*$ & & & & $*$ \\
\hline$-1,2$ & & $*$ & $*$ & $*$ & $*$ & * & * & * & * & & & \\
\hline 0,1 & $*$ & $*$ & & $*$ & $*$ & * & & $*$ & $*$ & & $*$ & * \\
\hline 0,2 & * & * & * & * & $*$ & * & $*$ & $*$ & $*$ & & & \\
\hline 1,2 & & * & $*$ & * & & * & & & & & & \\
\hline
\end{tabular}

+ VCS: Visual-Color Score ${ }^{1}$; t-test comparisons; GP: Grain Protein; KH: Kernel Hardness; KW: Kernel Weight.

* Significant difference in means between groups at $p=0.05$.

${ }^{1}$ Visual-color scores were determined in relation to the 1990 USDA-GIPSA color standard, with 0 as 'essentially equal' to the standard and +, and -scores as 'lighter' and 'darker' than the color standard, respectively.

as -1 and -2 as compared with the 0 sample group, but the $b^{*}$ values were not significantly different from +1 visual-color group. Lack of significant differences from the -1 and -2 visual-color groups may be related, in part, to the fewer number of samples that were scored as 'darker' than the color standard.

Distributions of $\mathrm{L}^{*}, \mathrm{a}^{*}$, and $\mathrm{b}^{*}$ values among hard white grain samples were examined in relation to visual-color scores. Although significant mean differences in colorimeter values were identified in the t-tests, $L^{*}, a^{*}$, and $b^{*}$ values were generally normally distributed with substantial overlap among the visualcolor groups (Figure 1). Grain colorimeter values also were obtained for a sample of the 1990 USDA-GIPSA color standard. The 1990 color standard had mean $\mathrm{L}^{*}$, $\mathrm{a}^{*}$, and $\mathrm{b}^{*}$ values of $41.35,4.63$, and 14.09 , respectively. Of the hard white samples obtained in 1996 and 1997, 39\% had lower $\mathrm{L}^{*}$ values as compared with the color standard, while 7 and $90 \%$ of samples had higher $a^{*}$ and $b^{*}$ values, respectively. There was no evidence to suggest that the colorimeter parameters could adequately differentiate among the visual-color groups. It is possible that the colorimeter was not able to capture the subtleties in kernel characteristics and light transmittance that impact visual-color scores. Conversely, the visual ratings may have been too imprecise to adequately differentiate among subtle shades of color that may be measured with the colorimeter.
There was a significant decrease in kernel hardness as visual-color scores increased above the color standard (Tables 1 and 2). An average reduction of 7.8 hardness units was associated with an improvement in visual-color scores from 0 to +1 , with an additional reduction of 5.1 hardness units from +1 to +2 scores. However, samples that scored darker than the color standard were not significantly different from those scored as 0 , or equal to the color standard. Grain protein content decreased an average of $10 \mathrm{~g} \mathrm{~kg}^{-1}$ in the +1 or +2 visual-color groups as compared with mean of the 0 or -1 groups. Kernel weight did not differ among samples with visual-color scores of -2 , $-1,0$, or 1 , but samples that scored +2 did average significantly heavier than the other groups.

Colorimeter measures of grain were highly correlated with kernel hardness (Table 3). Increasing kernel hardness resulting in a darker grain color, as indicated by negative correlations with grain $\mathrm{L}^{*}$ and $\mathrm{b}^{*}$ values. However, the corresponding $\mathrm{r}^{2}$ values were less than 0.40 , suggesting concurrent improvement in hardness and color would be possible. In contrast, variations in grain protein content and kernel weight had little or no relationship with variation in grain $\mathrm{L}^{*}, \mathrm{a}^{*}$, or $\mathrm{b}^{*}$ values.

It remains unclear how implementation of a visualcolor standard for classification might impact production, market demand, or utilization of U.S. hard 


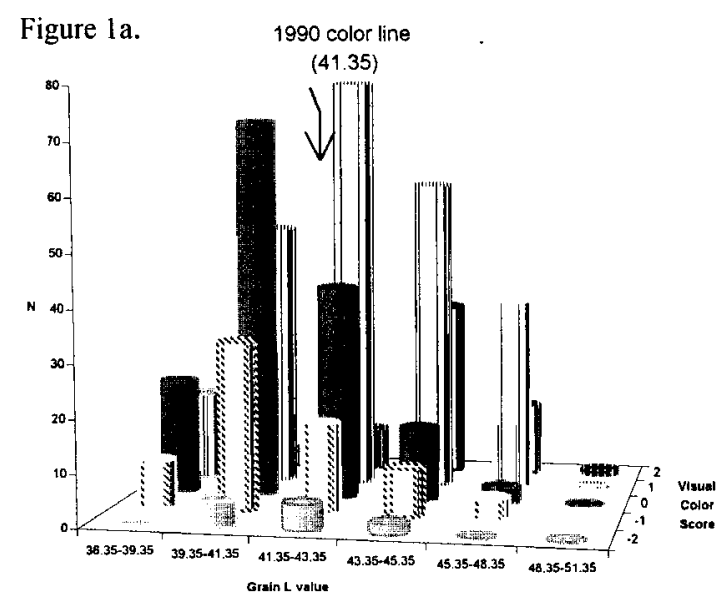

Figure lb.

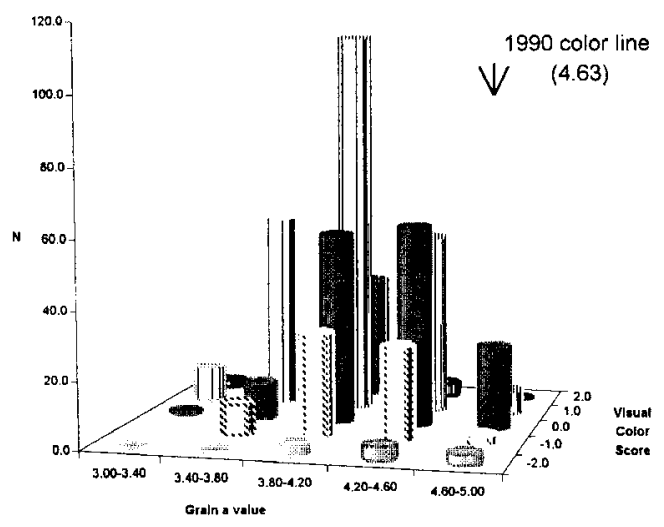

Figure 1c

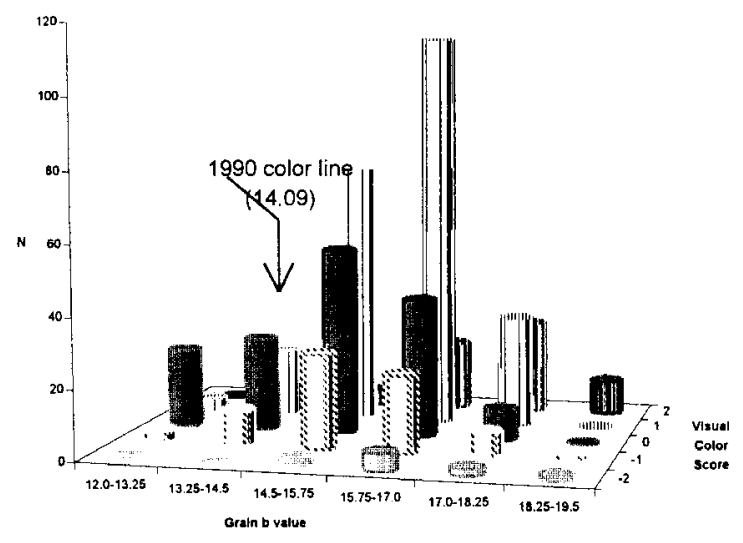

Figure 1. a, b, and c. Distribution of colorimeter $\mathrm{L}^{*}, \mathrm{a}^{*}$, and $\mathrm{b}^{*}$ values for hard white wheat grain samples in relation to visual-color scores. Colorimeter values for the 1990 USDA-GIPSA grain color standard are indicated. white wheat. For example, the industry has questioned whether variation in grain color has any relationship to processing value or end-product quality, such as color of whole grain breads. In this study, differences in grain visual-color scores did not translate into differences in ground meal $\mathrm{L}^{*}$ values (lightness). Grain samples with superior visual-color score of $+2 \mathrm{did}$ have higher meal $\mathrm{L}^{*}$ values than those of 0 or darker scores, but they did not differ from the +1 group. There was a decrease in $a^{*}$ value (redness) and $b^{*}$ value (yellowness) associated with improving grain color above the 0 color standard. However, t tests showed no difference in meal $\mathrm{a}^{*}$ and $\mathrm{b}^{*}$ values among samples with grain scores of $0,-1$, and -2 . Correlations among colorimeter parameters also confirm that grain color was a relatively poor indicator of ground meal color. Grain and meal $\mathrm{L}^{*}$ values were correlated at only $\mathrm{r}=$ 0.13 . Meal $L^{*}$ value decreased slightly in relation to increasing grain $b^{*}$ value $(r=0.40)$. Yellowness $\left(b^{*}\right)$ of meal increased with higher $\mathrm{L}^{*}$ value and decreasing $a^{*}$ and $b^{*}$ values for grain, but correlations were less than $r=0.30$. Variation in grain protein had a relatively greater influence on meal color, with correlation of $r=$ -0.53 between $\mathrm{L}^{*}$ and protein content.

Grain color, determined either by colorimeter or visual-scores, showed little relationship to flour color, with correlations less than $r=0.30$. Flour color did show significant relationship to color of ground meal. Decreasing grain $\mathrm{L}^{*}$ value and increasing grain $\mathrm{a}^{*}$ value were correlated with an increase in flour $a^{*}$ value, or redness. Flour $b^{*}$ value, or yellowness, also was significantly correlated with yellowness of meal. However, the flour-meal color relationships were likely inflated due to inefficiencies in bran separation associated with micro-milling and sifting of these small samples.

\section{Conclusions}

Selection for grain color and color stability over environments must be a high priority to ensure that new hard white varieties can meet USDA-GIPSA color standards and are acceptable for domestic and export marketing. However, care must be taken that when selecting for 'lighter' grain color, either through visual or colorimeter evaluations, that preferential selection for softer and less vitreous kernels is avoided and desired grain hardness and protein levels are maintained. In this study, colorimeter measures of grain color, although objective and highly repeatable, appear to have 
Table 3. Correlation coefficients among grain protein content, kernel hardness and weight, and colorimeter measures of grain, meal, and flour color for hard white wheat samples grown in 1996 and 1997

\begin{tabular}{|c|c|c|c|c|c|c|c|c|c|c|c|c|}
\hline & \multirow[t]{2}{*}{ GP } & \multirow[t]{2}{*}{ KG } & \multirow[t]{2}{*}{ KW } & \multirow[t]{2}{*}{ Grain } & \multicolumn{3}{|r|}{ Meal } & \multirow[b]{2}{*}{$\mathrm{L}^{*}$} & \multirow[b]{2}{*}{$\mathrm{a}^{*}$} & \multirow{2}{*}{$\begin{array}{l}\text { Flour } \\
b^{*}\end{array}$} & \multirow[b]{2}{*}{$\mathrm{L}^{*}$} & \multirow[b]{2}{*}{$\mathrm{a}^{*}$} \\
\hline & & & & & $\overline{L^{*}}$ & $\mathrm{a}^{*}$ & $\mathrm{~b}^{*}$ & & & & & \\
\hline $\mathrm{KH}$ & $-0.08^{*}$ & - & & & & & & & & & & \\
\hline $\mathrm{KW}$ & $-0.27^{* *}$ & $-0.15^{* *}$ & - & & & & & & & & & \\
\hline $\mathrm{KD}$ & $-0.12^{* *}$ & -0.07 & $0.92^{* *}$ & - & & & & & & & & \\
\hline \multicolumn{13}{|c|}{ Grain } \\
\hline $\mathrm{L}^{*}$ & 0.04 & $-0.63^{* *}$ & 0.07 & $0.11^{*}$ & - & & & & & & & \\
\hline$a^{*}$ & $-0.13^{* *}$ & $0.44^{* *}$ & -0.06 & -0.07 & $-0.55^{* *}$ & - & & & & & & \\
\hline$b^{*}$ & $-0.29^{* *}$ & $-0.48^{* *}$ & $0.15^{* *}$ & $0.15^{* *}$ & $0.64^{* *}$ & $-0.24^{* *}$ & - & & & & & \\
\hline \multicolumn{13}{|c|}{ Meal } \\
\hline $\mathrm{L}^{*}$ & $-0.53^{* *}$ & -0.03 & $0.19^{* *}$ & $0.15^{* *}$ & $0.13^{* *}$ & 0.02 & $0.04^{* *}$ & - & & & & \\
\hline$a^{*}$ & $0.41^{* *}$ & 0.06 & $-0.09^{*}$ & -0.05 & $-0.17^{* *}$ & $0.14^{* *}$ & $-0.36^{* *}$ & $-0.67^{* *}$ & - & & & \\
\hline$b^{*}$ & $-0.10^{*}$ & $0.44^{* *}$ & -0.01 & -0.01 & $-0.26^{* *}$ & $0.29^{* *}$ & $-0.22^{* *}$ & $-0.17^{* *}$ & 0.05 & - & & \\
\hline \multicolumn{13}{|c|}{ Flour } \\
\hline $\mathrm{L}^{*}$ & $-0.21^{* *}$ & $-0.31^{* *}$ & $-0.21^{* *}$ & $-0.29^{* *}$ & $0.12^{* *}$ & -0.06 & $0.27^{* *}$ & $0.25^{* *}$ & $-0.21^{* *}$ & $-0.30^{* *}$ & - & \\
\hline$a^{*}$ & $0.55^{* *}$ & 0.05 & $-0.10^{*}$ & 0.00 & 0.02 & $-0.12^{* *}$ & $-0.31^{* *}$ & $-0.43^{* *}$ & $0.53^{* *}$ & $-0.20^{* *}$ & $-0.32^{* *}$ & - \\
\hline $\mathrm{b}^{*}$ & $-0.26^{* *}$ & $0.36^{* *}$ & $0.12^{* *}$ & $0.10^{*}$ & $-0.28^{* *}$ & $0.31^{* *}$ & -0.01 & $0.18^{* *}$ & $-0.31^{* *}$ & $0.62^{* *}$ & $-0.10^{*}$ & $-0.65^{* *}$ \\
\hline
\end{tabular}

*, ** Significant at $\mathrm{P}=0.05$ and $\mathrm{P}=0.01$, respectively; GP: Grain Protein; KH: Kernel Hardness; KW: Kernel Weight; KD: Kernel Diameter.

little value in differentiating or predicting visual-color of hard white grain samples.

In 1999, USDA-GIPSA, in consultation with industry representatives, reinstated a visual-color standard for hard white wheat classification. The new color standard was based on a grain sample of 'Klasic' that is visually darker than the sample used prior to 1994. It is expected that the darker grain standard will reduce the probability for misclassification of hard white cultivars when grown over multiple environments. Interestingly, the new grain sample actually has higher colorimeter $\mathrm{L}^{*}$ value (42.60), and lower $\mathrm{a}^{*}(4.23)$ and $\mathrm{b}^{*}$ (13.74) values as compared with the 1990 standard; which would suggest it is actually 'lighter' and less red and yellow. This only reconfirms that environmental variations in grain color and subjective visual-color classification will remain a critical issue for breeders and producers of hard white wheat.

At least in the short term, classification of hard white grain based on visual-color will remain highly subjective. Unfortunately, hard white grain color, as determined either visually or by colorimeter, was not predictive of ground meal color or flour color. As such, it will not serve as a reliable indicator of grain quality, end-product color, or processing value to the milling and baking industries.

\section{References}

Freed, R.D., E.H. Everson, K. Ringlund \& M. Gullord, 1976. Seed coat in wheat and the relationship to seed dormancy at maturity. Cereal Res Commun 4: 147-148.

Morris, C.F., H.C. Jeffers \& D.A. Engle, 2000. Effect of processing, formula and measurement variables on alkaline noodle color toward an optimized laboratory system. Cer Chem 77: 77-85.

Reitan, L., 1980. Genetical aspects of seed dormancy in wheat related to seed coat color. Cereal Res Commun 8: 275-276.

Wu, J., B.F. Carver \& C.L. Goad, 1999. Kernel color variability of hard white and hard red winter wheat. Crop Sci 30: 634-638. 